\title{
Erratum to: The Effects of Exogenous Ascorbic Acid on the Mechanism of Physiological and Biochemical Responses to Nitrate Uptake in Two Rice Cultivars (Oryza sativa L.) Under Aluminum Stress
}

\author{
Xiaohua Zhou ${ }^{1,2} \cdot \mathrm{Zhaohu}_{\mathrm{Gu}^{2}} \cdot$ Huini $\mathrm{Xu}^{2} \cdot$ Limei $\mathrm{Chen}^{2} \cdot \mathrm{Guangxi} \mathrm{Tao}^{3}$. \\ Yongxiong $\mathrm{Yu}^{4} \cdot \mathrm{Kunzhi}^{\mathrm{Li}}{ }^{2}$
}

Published online: 2 March 2017

(C) Springer Science+Business Media New York 2017

\section{Erratum to: J Plant Growth Regul (2016) 35:1013-1024 \\ DOI 10.1007/s00344-016-9599-9}

Unfortunately, Fig. 5 was incorrect in the original publication of the article. The correct version of Fig. 5 is given below.

\section{Ascorbic Acid (AsA) Assay}

Roots ( $0.2 \mathrm{~g}$ fresh weight) were ground in a cold mortar and pestle with $10 \%(\mathrm{w} / \mathrm{v}) 1.5 \mathrm{~mL}$ trichloroacetic acid (TCA) and centrifuged at $20,000 \times g$ for $20 \mathrm{~min}$ at $4{ }^{\circ} \mathrm{C}$. From the supernatant a $200 \mu \mathrm{L}$ sample was used for the assay. For AsA determination $200 \mu \mathrm{L}$ of $150 \mathrm{mM} \mathrm{NaH}_{2} \mathrm{PO}_{4}$ buffer (pH7.4) and $200 \mu \mathrm{L}$ of water were added to the sample, then vortexed and incubated at room temperature for
$15 \mathrm{~min}$. Then $400 \mu \mathrm{L}$ of $10 \%(\mathrm{w} / \mathrm{v})$ trichloroacetic acid, $400 \mu \mathrm{L}$ of $44 \%(\mathrm{v} / \mathrm{v}) \mathrm{H}_{3} \mathrm{PO}_{4}, 400 \mu \mathrm{L}$ of $4 \%$ (w/v) bipyridyl in $70 \%$ (v/v) ethanol and $200 \mu \mathrm{L}$ of $3 \%$ (w/v) $\mathrm{FeCl}_{3}$, respectively were added. After vortexing the samples were incubated at $37^{\circ} \mathrm{C}$ for $60 \mathrm{~min}$ and the $\mathrm{A}_{525}$ was recorded. For the standard curve a solution of $1 \mathrm{mg} \mathrm{AsA} / \mathrm{mL}$ was prepared in 10\% TCA. In a series of dilutions using 10\% TCA AsA standard concentrations were made to a final concentration of 2, 4, 6, 8, $16 \mu \mathrm{g} / \mathrm{mL}$, respectively. A control without AsA was also included (0). The standards and the control were handled for spectrophotometric determination of AsA as described above.

The online version of the original article can be found under doi:10.1007/s00344-016-9599-9.

Kunzhi Li

likzkm@163.com

1 Faculty of Environmental Science and Engineering, Kunming University of Science and Technology, Kunming 650500, China

2 Biotechnology Research Centre, Faculty of Life Science and Biotechnology, Kunming University of Science and Technology, Jingming South Road, Chenggong Campus, Kunming 650500, Yunnan, China

3 Rice Institute, Agriculture University of Yunnan, Kunming 650201, Yunnan, China

4 College of Zoological Science and Technology, Southwest University, Chongqing 400715, China 


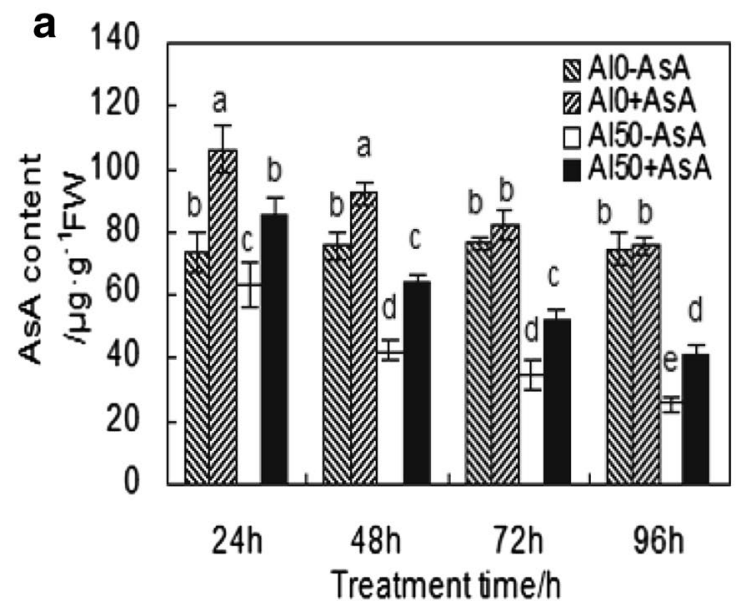

Fig. 5 Effects of exogenous AsA on the endogenous AsA content in PA1 and PS5 under Al stress for different periods of time. The endogenous AsA content in PA1 (a) and PS5 (b) roots. The values

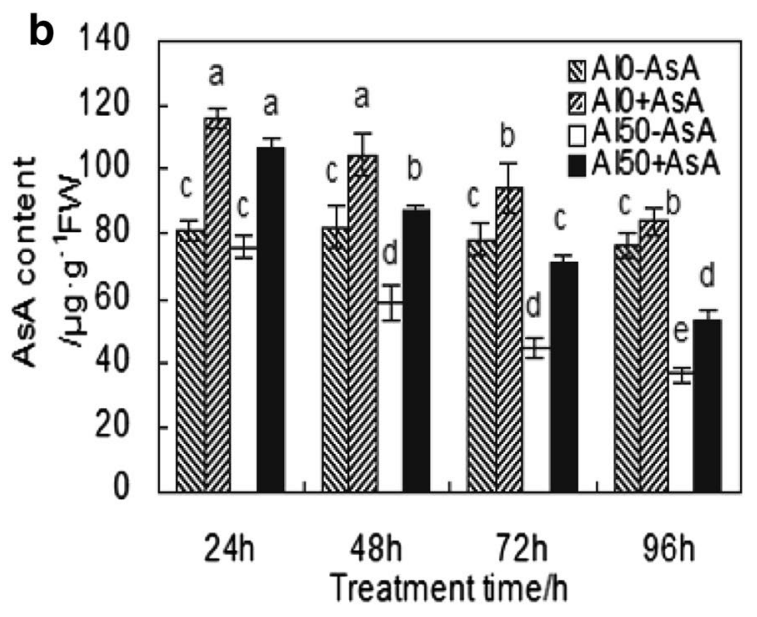

represent the mean $\pm \mathrm{SD}(n=3)$. Different letters in thesame columnor cultivar indicate that the values are significantly different at the 0.05 level, according to Duncan's multiple range test 